\title{
A Charadriiformes madárrend fajainak vonulása és fészkelése Kevermesen és Lőkösházán
}

\author{
BOZÓ LÁSZLÓ \\ 5744 Kevermes, Battonyai u. 10. \\ E-mail: bozolaszlo91@gmail.com
}

\begin{abstract}
Összefoglalás. A dolgozatban a Charadriiformes madárrend tagjainak vonulását és a fészkelő fajokat vizsgáltam meg a Csanádi-hát kevermesi és lőkösházi területegységén. 2004 és 2016 között 34 madárfaj jelenlétét sikerült bizonyítanom a térségben, melyek nagy része csak átvonulóként van jelen, csupán 5 faj fészkel. Mind a fészkelö, mind az átvonuló fajok számát az aktuális tavaszi belvizek kiterjedése határozta meg és a ritka fajok is a kifejezetten belvizes években kerültek szem elé. A legtöbb faj a belvízzel borított szántókat részesítette előnyben a bányatavakkal szemben, ezért ősszel a vizek kiszáradása miatt jóval kisebb számban mutatkoztak, mint tavasszal.
\end{abstract}

Kulcsszavak: lilealakúak, madárvonulás, belvizes területek, Csanádi-hát

\section{Bevezetés}

A Dél-Alföldön sok kiváló vizes élőhelyet találhatunk, melyek között több nagyobb halastavat, szikes tavakat, mesterséges tavakat, folyókat és időszakos vízborítottságú területeket is fellelhetünk. Ezek egy része ramsari terület, mint például a kardoskúti Fehér-tó, vagy a Biharugrai-halastavak (TARDY 2007), sok azonban annak ellenére rendkívül gazdag természeti értékekben, hogy nem áll jogi védelem alatt. A táj bizonyos részein ezzel szemben alig találhatunk vizeket, így azok ottani jelenléte kiemelt fontosságú. Ilyen tájegység a Csanádi-löszhát is, itt ugyanis csak elvétve bukkanhatunk vizes élőhelyekre. A térségben még a történelmi időkben sem volt jellemző ez az élöhely típus, mivel nagyrészt a végeláthatatlan löszpuszták határozták meg a képet (CSATHÓ 2008, CSATHÓ \& CSATHÓ 2009, TÓTH 2003). Egykoron a Maros itt kanyargott, de ennek nyomait ma már csak a Száraz-ér és néhány fattyúág hordozza (PELLE 2003). Állandóan vízzel borított vízfelületnek csak a kisszámú bányató számít, amik nem feltétlenül kedveznek változatos élővilág kialakulásának. Sokkal inkább jellemzőek az időszakos vízállások, mint amilyenek a belvizes szántók. Ezek megléte az aktuális csapadékviszonyoktól függ, száraz időszakokban olykor egyáltalán nincsenek jelen, ellenkező esetben viszont nagy kiterjedésű belvizek alakulhatnak ki (BozÓ 2015). A 20. századbeli csatornázások következtében ezek is csak a legmélyebb részeken tudnak hosszabb távon megmaradni. Összességében tehát elmondható, hogy a térségben nincsenek kedvező feltételek a vizes élöhelyekhez kötődő madárfajok számára. 
A térségben 2005 óta zajlanak aktív madártani kutatások, amelyek elsősorban a vízi, ill. az énekesmadarakkal foglalkoznak, ezen belül is kifejezetten a fajok vonulására fókuszálnak (Bozó 2015a, 2015b, 2015c, BozÓ 2017, Bozó et al. in press). Ebben az időszakban 241 faj közel 50000 adata gyült össze, így lehetőség nyílik a fajok térségbeli helyzetének értékelésére. A vizsgálatomba bevont madárfajok nagy része elsősorban a nagyobb halastavakhoz, vizes pusztákhoz és szikes tavakhoz kötődik, mint ahogy azt több dél-alföldi tanulmányban is jól láthatjuk (KACZKó 1992, KOTYMÁn 1996, STERBETZ 1993, TóTHNÉ HANYECZ 2006, ZALAI 1999). Több éves megfigyelések során azonban még az olyan száraz vidékeken, mint amilyen a Csanádi-hát is előkerülhetnek ezek a fajok, habár nyilvánvalóan viszonylag kis egyedszámban. KOTYMÁN (2003) cikkében egy aszályos év partimadár mozgalmait mutatta be több dél-tiszántúli vizes élőhelyen. Jelen tanulmányban hasonlóan kívánom bemutatni saját, 2004 és 2016 közötti, lilealkatúakra vonatkozó adataim alapján ezen fajok helyi mozgalmait, a jellemző elökerülési idők és esetleges költési adatok megadásával, valamint elvégzem az egyes fajok tavaszi- és őszi vonulásának összevetését.

\section{Anyag és módszer}

Az adatok Kevermes és Lőkösháza települések mintegy 8000 hektáros kül- és belterületéről származnak a 2004 és 2016 közötti időszakból. A kutatásomba bevont terület határának a települések közigazgatási határát tekintettem (1-2. ábrák).

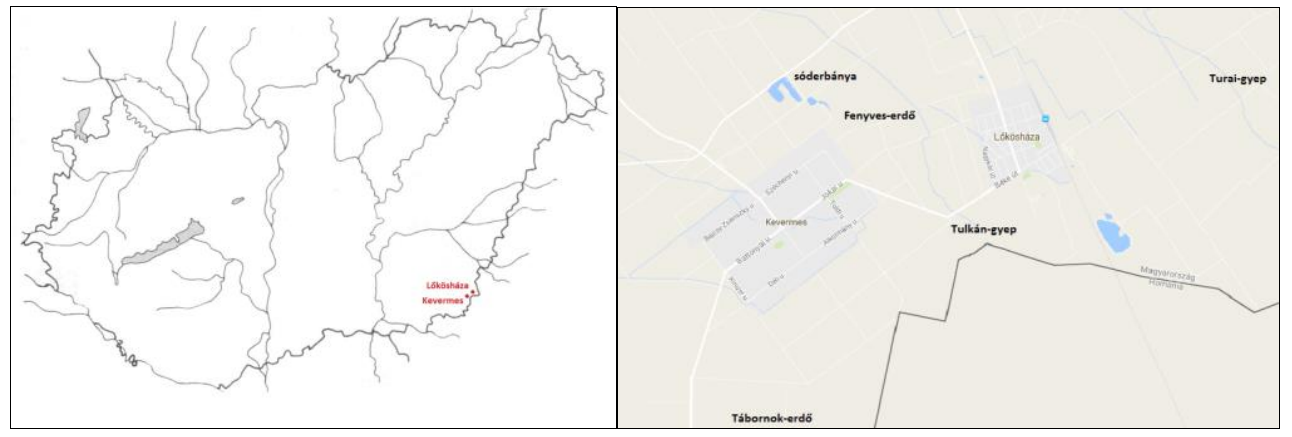

1-2. ábra. A kutatási terület országon belüli elhelyezkedése, valamint a térség részletes, legfontosabb élöhelyeit bemutató térképe.

Figures 1-2. The location of the research area within Hungary and detailed map of the region with the most important habitats.

A különbözö években történt megfigyelési napok számát és a pontos megfigyelései időszakokat az 1. táblázat ismerteti.

A megfigyeléseket a terület kerékpáros és gyalogos bejárásával, kézitávcső és fényképezőgép használatával végeztem. Csak azokat a madarakat írtam fel, amelyeket minden kétséget kizáróan meg tudtam határozni. Adatnak minden megfigyelési nap összesített példányszáma számít. A térség legértékesebb vizes élőhelyei a kevermesi sóderbánya, illetve a 
lőkösházi Turai-gyep, a megfigyelések jelentős része ezen a két helyen történt. Elöbbi egy mesterséges bányatórendszer, a nyílt vízfelület kiterjedése mintegy 20 hektár. Partimadarak táplálkozására alkalmas iszappadok, homokzátonyok nincsenek. A Turai-gyep egy kb. 120 hektáros Natura 2000-es mély fekvésü, mocsaras terület (mocsári nőszirommal, zsiókával), ahol a magasabb részeken szikpadkák is vannak értékes növényzettel (pl. réti őszirózsa, sziki üröm, magyar sóvirág).

1. táblázat. Az évenkénti megfigyelési napok száma és a megfigyelési időszakok.

Table 1. Number of the observation's days and the annual periods of the observations.

\begin{tabular}{ccc} 
Év & Megfigyelési napok száma & Időszak \\
\hline 2004 & 25 & október 23. - december 31. \\
2005 & 115 & január 8. - december 31. \\
2006 & 99 & január 1. - december 31. \\
2007 & 97 & január 2. - december 31. \\
2008 & 62 & január 3. - december 25. \\
2009 & 72 & január 12. - december 28. \\
2010 & 22 & január 9. - december 23. \\
2011 & 11 & január 4. - december 22. \\
2012 & 54 & január 18. - december 27. \\
2013 & 204 & január 2. - december 31. \\
2014 & 193 & január 2. - december 31. \\
2015 & 165 & január 1. - december 17. \\
2016 & 161 & január 4. - december 31.
\end{tabular}

A gyep körüli szántók csapadékos években $(2010,2013)$ víz alá kerülnek, és rajtuk ekkor kb. 1-2 hektár kiterjedésü belvizes foltok alakulnak ki, amelyek július közepére száradnak ki. Ha kevesebb csapadék hullott az ösztől tavaszig terjedő időszakban, akkor csak néhány 100 négyzetmétert borít el a víz. További fontos és említésre méltó terület a Tulkángyep, ahol csak 2013-ban volt kisebb kiterjedésü belvíz. Ez a gyep egy korábban felszántott, 8 hektáros kaszáló, jelentősebb botanikai értékek nélkül. Több adat származik a Fenyves-erdő és a Tábornok-erdő területéről is. Mindkettő mesterségesen telepített erdő, utóbbi egy mélyebb laposban helyezkedik el, így minden évben megáll benne a víz egy kb. 1 hektáros területen (a területek részletes bemutatásához lásd Bozó (2017) munkáját). A 34 megfigyelt madárfaj térségbeli státuszát több nézőpontból közelítettem meg. Ritkának tekintettem azokat, amelyeknek a teljes vizsgálati időszakból 5-nél kevesebb (általában maximum 3) adata ismert a térségből (10 faj 24 adata). A fennmaradó 24 fajnál megvizsgáltam a jellemző előfordulási időket. Általában kettéválasztottam a tavaszi és az őszi vonulást és külön elemeztem azokat, azonban néhány esetben erre nem volt lehetöség a kevés adat miatt (pl. az erdei szalonka (Scolopax rusticola) esetében a sok őszi megfigyeléssel szemben csak 2 tavaszi megfigyelés történt). Tavasznak a legtöbb faj esetében a március 1 . és május 31 . közti időszakot tekintettem, míg az ősz, az őszi vonulási időszaknak megfelelően, június 
25. és november 30. közé esik. Költési időszaknak az április 30. és június 30. közötti időszakot tekintettem, ugyanakkor a bíbic esetében már április elején is előfordultak tojásos fészkek, míg több faj májusban még vonult. Ennek megfelelően az egyedi sajátosságokat minden esetben figyelembe vettem. A 846 összes adatból így 24 adat a ritka fajokra, míg 768 a rendszeresen előforduló fajok vonulására vonatkozik, a fennmaradó 54 pedig a fészkelö fajok költési időszakban történő megfigyelésére utal. Külön tárgyalom ugyanis a fészkelési adatokat. A szövegben található ábrák a Microsoft Excel program felhasználásával készültek. A fajok bemutatása rendszertani sorrendben történik, amely sorrend a Magyarország madarainak névjegyzéke (MME NOMENCLATOR BIZOTTSÁG 2008) alapján lett összeállítva.

\section{Eredmények}

\section{Rendszeres átvonulók és fészkelök}

\section{Gólyatöcs (Himantopus himantopus)}

21 adata ismert a tárgyalt térségből, melyek kivétel nélkül a tavaszi, ill. a költési időszakból származnak (3. ábra). Tavasszal legkorábban 2013. április 11-én észleltem 4 példányt a Turai-gyep melletti belvizes szántón. Általában kisebb csapatokban láthatók, legnagyobb csapata 40 példányból állt (2013. május 4., Turai-gyeppel határos belvizes szántó). Ezek a példányok kevésbé összetartók, mint például a gulipánok, gyakran szétszóródva mozognak. Az adatok 95,2\%-a a Turai-gyepről származik, Kevermesen, távol a vizektől csak 2016. május 17-én figyeltem meg 1 magányos, átrepülö példányt.

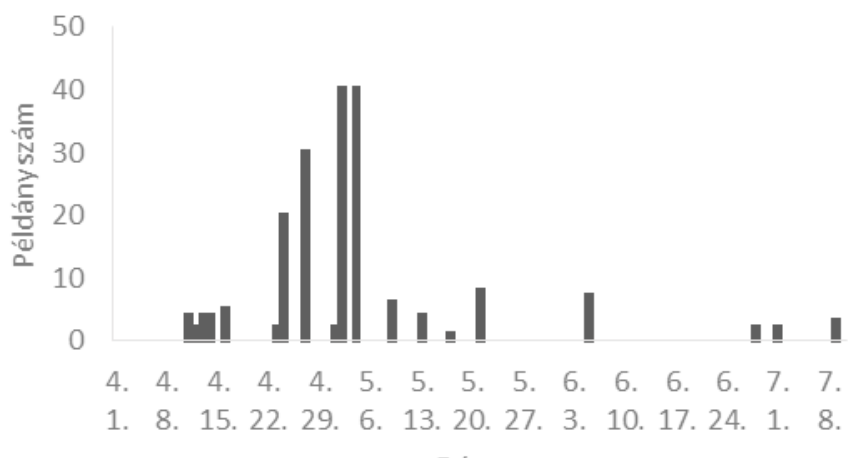

Dátum

3. ábra. A gólyatöcs tavaszi vonulási dinamikája és költési időbeli megfigyelései.

Figure 3. The spring migration dynamics and the observations in the breeding period of black-winged stilt.

A vonulás április 20. és május 5. között tetőzik, ezután már csak azok a madarak láthatók, amelyek megpróbálkoznak a fészkeléssel. 2010-ben és 2013-ban is csak 1-1 pár költött 
sikeresen a Turai-gyeppel határos belvizes szántókon, holott 2013 áprilisának végén legalább 5-6 pár kezdte el a költést, és még június 5-én is 3 pár mozgott itt. A belvizek kiszáradása azonban meghiúsította a költéseket, csak egy, zsiókás-sásos foltban költő pár repített egy fiókát. Ezt a családot július 9-én láttam utoljára a területen. Öszi adata nincs, aminek egyértelmüen az az oka, hogy a belvizek akkorra már kiszáradnak.

\section{Gulipán (Recurvirostra avosetta)}

14 adata ismert a tárgyalt térségböl, melyek kivétel nélkül a tavaszi, ill. a költési időszakból származnak (4. ábra). Tavasszal az első példányok általában április második hetében tünnek fel a belvizes szántókon, de van egy 2015. március 14-i adata is a Turai-gyeppel határos belvizes szántókról. Az áprilisban megjelenő madarak 10-30 példányos, általában összetartó csapatokban mozognak, magányos példányok egyáltalán nem kerültek még szem elé (legnagyobb csapata: 2013. április 11., Turai-gyeppel határos belvizes szántó, 30 példány). Minden adata a Turai-gyepről származik, Kevermesen a vizsgálati időszakban nem került elő. A 14 adatból 13 2013-ból, míg 1-1 2010-ből és 2015-ből származik. A vonulás március közepe és április vége között zajlik (legkorábbi megfigyelés: 2015. március 14. Turai-gyeppel határos belvizes szántó, 2 pld.; legkésőbbi megfigyelés, amely átvonuló madarakra vonatkozik: 2013. április 27., Turai-gyeppel határos belvizes szántó, 20 pld.), ezt követően megtévesztő a megfigyelések magas száma, ezek ugyanis valószínűleg már a fészkelő egyedekre vonatkoznak. A Turai-gyeppel határos belvizes szántókon 2010-ben és 2013-ban is sikeresen költött 1-1 pár, ugyanakkor a költési siker rendkívül alacsony a belvizek kiszáradása miatt. 2013-ban legalább 10 pár kezdett költésbe április végén, majd ezt követően június 5 -én már csak 2, a hó közepén pedig 1 pár mozgott a területen. Öszi adata nincs.

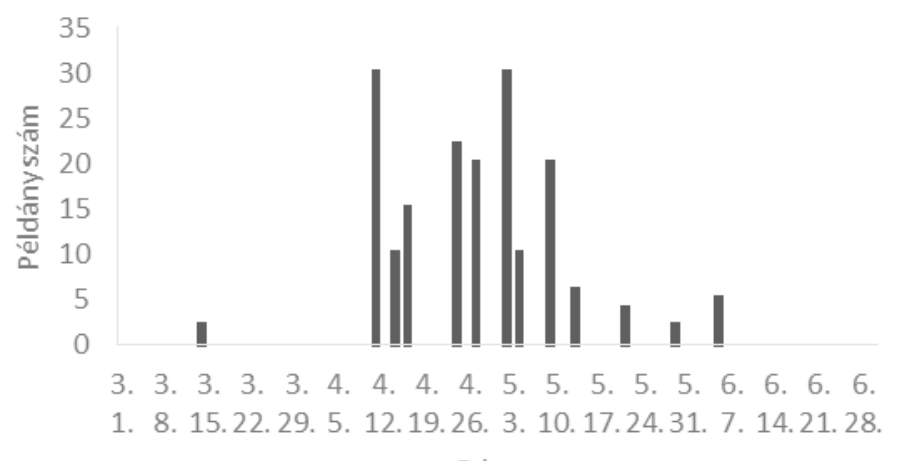

Dátum

4. ábra. A gulipán tavaszi vonulási dinamikája és a költési időbeli adatai.

Figure 4. The spring migration dynamics and the observations in the breeding period of pied avocet. 


\section{Kis lile (Charadrius dubius)}

2005 óta minden évben sikeresen költ egy pár a sóderbánya területén. Ezek a madarak április elején térnek vissza a költőhelyre és ott általában június végéig, de legkésőbb július legelejéig láthatóak (legkésőbbi megfigyelés: 2014. július 2., sóderbánya, 3 pld.). A fészek helyét csak egyszer találtam meg, ami egy nyílt, sík, homokos felszínen volt. Általában a fiatalokat vezetgető szülők alapján sikerült bizonyítani a költést. 2013-ban legalább egy pár a Turai-gyep menti belvízen is sikeresen költött és itt is hasonló időpontban, július 1-jén láttam az utolsó madarakat. A költési időben történő megfigyelésektől eltekintve összesen 23 adata ismert a térségből, 17 a tavaszi, míg 6 az őszi vonulási időszakból (5. ábra). Ennél a fajnál tehát már van őszi adat is, valószínüleg annak köszönhetőn, hogy ez a sóderbánya területén is megfelelő pihenő- és táplálkozóhelyeket talál a vonulás során. Az adatok jelentős része (köztük minden őszi) innen származik, a Turai-gyepen csak a nagyobb belvizek alkalmával került szem elé. Tavasszal március vége és április vége közt találkozhatunk átvonuló egyedekkel (legkorábbi megfigyelés: 2010. március 20., sóderbánya, 2 pld.; legkésőbbi megfigyelés: 2013. április 24., Turai-gyeppel határos belvizes szántó, 1 pld.). A vonulás csúcsa március vége és április közepe között van. Általában magányosan, vagy néhány példányos csapatokban látható (legnagyobb csapat: 2015. április 16., Turai-gyeppel határos belvizes szántó, 6 pld.). A költések befejezése (június legvége, július eleje) utáni másfél hónapból egyetlen adata sincs Az őszi átvonulók augusztus közepén jelennek meg (legkorábbi megfigyelés: 2009. augusztus 11., sóderbánya, 1 pld.) és a hó végére az utolsók is eltünnek (legkésőbbi megfigyelés: 2009. augusztus 30., sóderbánya, 1 pld.). Nem nevezhető rendszeres őszi átvonulónak, hiszen a 6 adat 2 évből (2008 és 2009) származik.

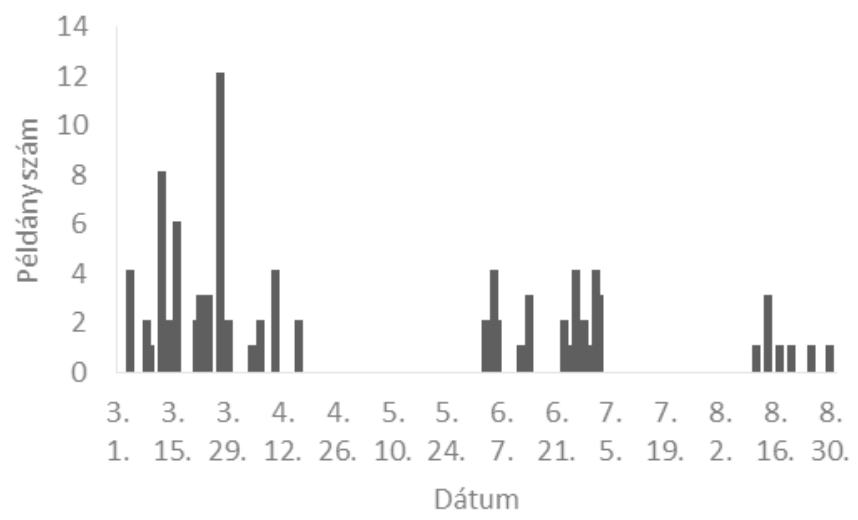

5. ábra. A kis lile megfigyelési adatai.

Figure 5. Observation data of little ringed plover.

Aranylile (Pluvialis apricaria)

20 adata ismert a tárgyalt térségben, ebből 17 a tavaszi, míg 3 az öszi időszakból származik. Tavaszi vonulása elhúzódó, az első csapatok már február közepén megjelenhetnek 
(legkorábbi megfigyelés: 2014. február 12., Kevermes, Bécsi-dűlő, 48 pld.), míg az utolsók április közepén tünnek el (legkésőbbi megfigyelés: 2013. április 11., Turai-gyep, 1 pld.). A vonulás csúcsa márciusban van, hó közepi tetőzéssel. Ekkor 100-300 példányos csapatai sem ritkák a Turai-gyep menti belvizes területeken (legnagyobb csapata: 2015. március 14., Turai-gyeppel határos belvizes szántó, kb. 300 pld.). Mindig csapatokban látható, magányos példányai még nem kerültek szem elé. Összel szintén tág intervallumon belül, szeptember eleje és november vége között került elő (legkorábbi megfigyelés: 2016. szeptember 1., Kevermes, fácántelep, 4 pld.). Mivel két különbözö évben is előkerült szeptember első napjaiban, valószínüsíthető egy szeptember eleji vonulási időszak, ami egyezik az ország más részein megfigyelt mintázattal (HADARICS \& PELLINGER 2009).

\section{Bíbic (Vanellus vanellus)}

Rendszeres, változó számú fészkelő a térségben. Állományát az ősztöl tavaszig lehulló csapadék mennyisége nagyban befolyásolja. Legnagyobb állománya minden évben a Turaigyep környékén költ, itt belvizes években (2010 és 2013) akár 20 pár is megpróbálkozhat a költéssel. Ez azonban nem feltétlenül jelent sikeres fészkelést, mert ha gyorsan kiszáradnak a belvizek, akkor a fészekaljak (mint látni fogjuk a későbbiekben tárgyalt fajoknál is) tönkre mennek. Az eddigi legnagyobb állomány, mintegy 30 pár 2013-ban költött a térségben. Egy esetben előfordult olyan is, hogy vizektől távolabb, szántáson rakták le a tojásaikat (Frank Máté szóbeli közlése).

264 adata ismert az őszi és tavaszi vonulási időszakból, amellyel a leggyakoribb az itt tárgyalt fajok közül (6. ábra). Minden évböl van adata, a legtöbb (93) 2013-ból származik, ami jelzi, hogy a belvizek kulcsfontosságúak még ennél a fajnál is. Ez az év kiemelkedik a többi közül, nemcsak a megfigyelések számát, hanem a költési sikert tekintve is, hiszen a költések után ebben az évben lehetett megfigyelni a legnagyobb, fiatalokból álló csapatokat a költőhelyeken (2013. július 1., Turai-gyep, 200 pld.). Azon fajok egyike, amely az utóbbi években mind gyakrabban telel át nálunk, így például a Turai-gyepen minden évben látható 5-50 áttelelő példány. Szinte mindig csapatokban látható, az év bizonyos szakaszaiban kisebb, míg máskor akár több száz példányos csoportosulásai sem ritkák. Tavaszi vonulása február közepén kezdődik el (legkorábbi megfigyelés: 2014. február 10., Kevermes, Fenyves-erdő, 5 átrepülő pld.) és egészen április elejéig tart, ugyanakkor az áprilisi átvonulókat már nehéz elkülöníteni a helyben fészkelőkkel. Csúcsa márciusban van, egyértelmü tetőzés azonban nincs. A csapatok jellemzően 50 példány alattiak, ennél több példányt csak kivételesen lehet látni (2013. április 11., Turai-gyeppel határos belvizes szántó, 110 pld.; 2014. március 18., Turai-gyeppel határos belvizes szántó, 150 pld.; 2015. március 14., Turaigyeppel határos belvizes szántó, 200 pld.). Április elejétôl nagyrészt már csak azok a madarak maradnak itt, amik megpróbálkoznak a költéssel. A költés után, június második felétől kezdve kisebb-nagyobb csapatokban gyülekeznek, amely csapatok nagy részét az az évi fiatalok teszik ki, így létszámuk a sikeres költések számának függvényében alakul. A legnagyobb (200 példány) csapat nem meglepő módon 2013. július 1-jén került szem elé a Turaigyepen. Ez a gyülekezés július végéig tart, majd egy több mint egy hónapos „csend” következik, amikor szinte egyáltalán nem került elő a faj. Szeptember elején már ismét lehet vele találkozni, az őszi vonulás azonban csak a hó második felében kezdődik el (legkorábbi megfigyelés: 2013. szeptember 15., Turai-gyep, 25 pld.) és egészen november közepéig tart (legkésőbbi megfigyelés: 2012. november 18., sóderbánya, 5 pld.). Csúcsa október közepe 
és november eleje között van. Ekkor nem ritkák 150-400 példányos napi maximumai sem (legnagyobb csapat: 2013. szeptember 22., Turai-gyep, kb. 400 pld.), nagy csapatai azonban nem jellemzőek. November közepére lecseng a vonulásuk, ezt követően csak az áttelelők láthatók. Összességében tehát elmondható, hogy 3 nagyobb mozgalma van a bíbicnek a térségben, egy tavasszal, egy a költések után, egy pedig összel.

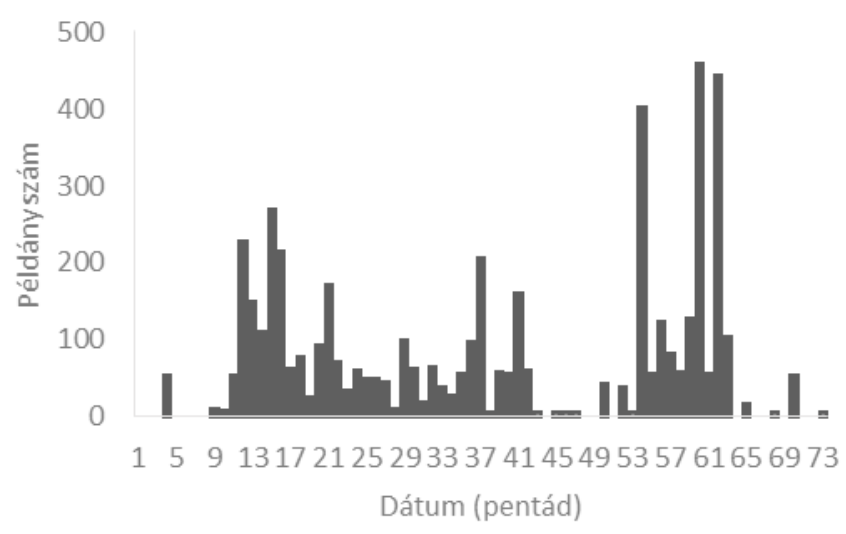

6. ábra. A bíbic pentádonkénti megfigyelési adatai.

Figure 6. Observation data of northern lapwing by pentads.

\section{Pajzsoscankó (Philomachus pugnax)}

13 adata ismert a térségből, amelyek közül 11 a tavaszi időszakból származik (7. ábra). Egy kivétellel minden esetben a Turai-gyep környékén került elő (kivétel: 2013. április 17., sóderbánya, 50 átrepülő pld.). Tavasszal március közepe (legkorábbi megfigyelés: 2015. március 14., Turai-gyep, 1 pld.) és május első hete (legkésőbbi megfigyelés: 2013. május 9., Turai-gyeppel határos belvizes szántó, 4 pld.) között vonul át a térségben. A vonulás csúcsa április közepe és május első napjai között van, ekkor akár 40-50 példányos csapatait is megfigyelhetjük a Turai-gyep melletti belvizeken. Mindkét őszi adata 2013 júliusából származik a Turai-gyeppel határos belvizekről (július 12., 3 pld.; július 15., 1 pld). Egyértelmüen az az oka az őszi adatok hiányának, hogy nincsenek megfelelő vizes élőhelyek, ahol a pajzsoscankók (és más fajok) tudnának pihenni és táplálkozni. 


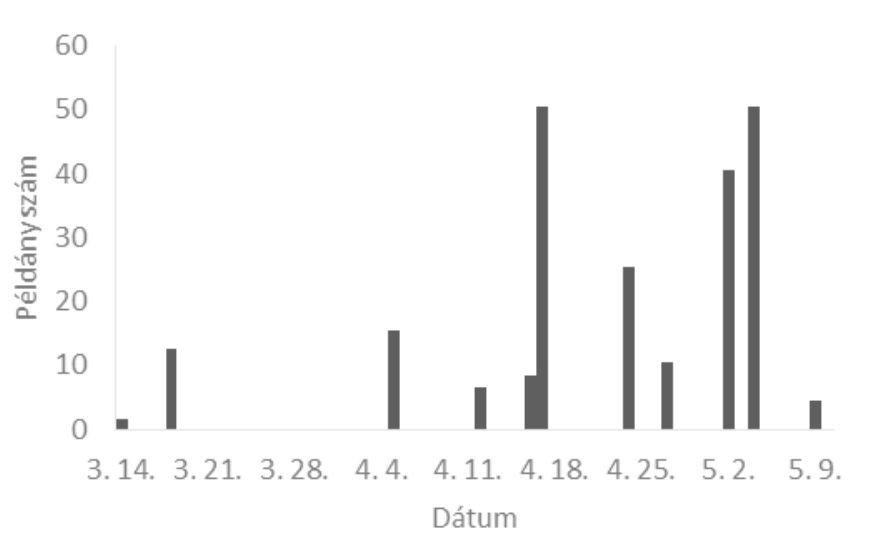

7. ábra. A pajzsoscankó tavaszi vonulási dinamikája.

Figure 7. Spring migration dynamics of ruff.

\section{Sárszalonka (Gallinago gallinago)}

18 adata ismert a térségből, 10 a tavaszi, míg 8 az őszi vonulási időszakból (8. ábra). Tavasszal szinte kizárólag a Turai-gyep vizenyős részein és a környék belvizein került szem elé, ősszel viszont tulajdonképpen bárhol felbukkanhatnak átrepülő egyedek (köszönhetően annak, hogy a vizes élőhelyek addigra nagyrészt kiszáradnak). Tavaszi vonulása március első felében indul (legkorábbi megfigyelés: 2015. március 14., Turai-gyep, 20 pld.) és egészen április közepéig tart. A 2013-as nagy belvizek idején még május 13-án is szem elé került egy példány a gyepen, de ez kivételes esetnek számít. Nincs határozott csúcs, elöfordult, hogy már március közepén legalább 30 példány tartózkodott a gyepen (2015-ben), de hasonló egyedszámokat április első felében is lehet tapasztalni (pl. 2016. április 12., Turai-gyep, 15 pld.). Érdekes, hogy 2013-ban a nagy belvizek ellenére is csak néhány példány került elő. Úgy tünik, hogy hullámokban érkeznek meg tavasszal, amik nem feltétlenül vannak időszakhoz kötve. Összel szeptemberben és október elején vonul át a térségen, azonban fontos megemlíteni, hogy van július eleji és november végi adata is. A július eleji megfigyelések 2013-ban történtek (július 9., Turai-gyep, 2 pld.), amikor még nyár közepén is voltak belvizek és ezek a madarak valószínüleg a költések utáni diszperzióval elinduló fiatalok lehettek. A november végi megfigyelés (2012. november 18., Turai-gyep, 2 pld.) pedig arra enged következtetni, hogy kis számban a szeptember-október eleji csúcstól később is átmegy a térségen. 


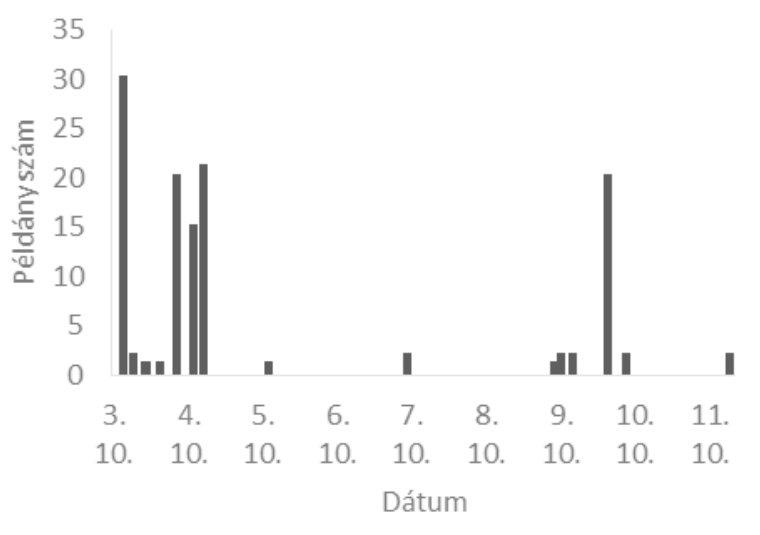

8. ábra. A sárszalonka éves vonulási dinamikája.

Figure 8. Annual migration dynamics of common snipe.

\section{Nagy sárszalonka (Gallinago media)}

4 különböző évböl összesen 6 adata ismert a térségből (2. táblázat). Minden adat a tavaszi időszakból, a Turai-gyepről származik. Április 12. és május 21. között zajlik a tavaszi vonulása, egyértelmü csúcs nincs, ugyanakkor 2 adat is április és május fordulójáról származik. Mindig magányos példányok kerültek szem elé, a gyepen tartózkodó madarak száma pedig csak egyszer érte el a két példányt (2015. április 16.). Elképzelhető, hogy ennél valamivel nagyobb számban vonul át nálunk, csupán rendkívül nehéz a madarak detektálása.

2. táblázat. A nagy sárszalonka előfordulási adatai.

Table 2. Observation data of great snipe.

Időpont

2011. április 29.

2011. május 7.

2013. április 27.

2013. május 21.

2015. április 16.

2016. április 12.

Példányszám

1

1

1

1 Lőkösháza, Turai-gyep

1 Lőkösháza, Turai-gyep

2 Lőkösháza, Turai-gyep

1 Lőkösháza, Turai-gyep
Megfigyelö(k)

Bozó L.

Bozó L.

Bozó L.

Bozó L.

Bozó L.

Bozó L.

\section{Erdei szalonka (Scolopax rusticola)}

10 adata ismert a térségből, 2 a tavaszi, míg 8 az őszi-téli időszakból (3. táblázat). Öszi vonulása sokkal erősebb, mint a tavaszi. Az első madarak szeptember végén jelennek meg (legkorábbi megfigyelés: 2008. szeptember 27., sóderbánya, 1 pld.), november elejéig 
azonban kifejezetten ritka. A vonulás csúcsa november első két hetében van, ezt követően hirtelen eltünnek a térségből (legkésőbbi megfigyelés: 2015. november 13., sóderbánya, 1 pld.) és csak enyhe teleken bukkannak fel áttelelő példányok (pl. 2013/14 tele). Tavasszal egy március eleji és április eleji megfigyelésre támaszkodhatunk, amiből nem lehet meghatározni pontos vonulási időszakot. Szinte bármilyen fás élöhelyen felbukkanhatnak magányos példányok, de kifejezetten szereti a sürü ezüstfásokat, ahol nyiladékokat is talál magának.

3. táblázat. Az erdei szalonka előfordulási adatai.

Table 3. Observation data of eurasian woodcock.

\begin{tabular}{lcll}
\multicolumn{1}{c}{ Időpont } & Példányszám & \multicolumn{1}{c}{ Terület } & \multicolumn{1}{c}{ Megfigyelö(k) } \\
\hline 2008. szeptember 27. & 1 & Kevermes, sóderbánya & Bozó L., Sipos T. \\
2009. december 17. & 1 & Kevermes, Fenyves-erdő & Bozó L., Simon-Csatlós Z. \\
2011. november 12. & 1 & Kevermes, sóderbánya & Bozó L., Rozgonyi J. \\
2012. november 09. & 1 & Kevermes, Fenyves-erdő & Bozó L. \\
2013. április 06. & 1 & Kevermes, Fenyves-erdő & Bozó L. \\
2013. december 07. & 1 & $\begin{array}{l}\text { Kevermes, Fenyves-erdő } \\
\text { Lőkösháza, Tulkán-gyep }\end{array}$ & Bozó L. \\
2014. március 08. & 1 & melletti ezüstfás & Bozó L. \\
2015. november 03. & 1 & Kevermes, lödomb & Bozóné Borbáth E., Bozó L. \\
2015. november 13. & 1 & Kevermes, sóderbánya & Bozóné Borbáth E., Bozó L. \\
2016. október 07. & 1 & Kevermes, fácántelep & Bozó L. \\
2016. október 19. & 1 & Kevermes, sóderbánya & Bozó L. \\
2016. október 31. & 1 & Kevermes, fácántelep & Bozó L.
\end{tabular}

\section{Kis póling (Numenius phaeopus)}

20 adata közül 16 a tavaszi, míg 4 az öszi időszakból származik, tehát ez is nagyrészt tavaszi átvonulónak tekinthető (9. ábra). Minden tavaszi adata a március vége és április vége közötti időszakból való, tehát egy viszonylag szük perióduson belül vonul át nálunk (legkorábbi megfigyelés: 2010. március 20., sóderbánya, 30+25 átrepülő pld.). A csúcs április első két hetében van, a legnagyobb példányszámú csapatok április közepén kerültek szem elé. A csapatok átlagos létszáma 15-35 példány, csupán egy 150 példányos csapatát figyeltem meg 2014. április 19-én a sóderbánya felett. Nem ragaszkodik a vizes élőhelyekhez, általában átrepülő madarakkal lehet találkozni, de két alkalommal már szántón és lucernáson is megfigyeltem. Alkalmanként egy-egy nagy póling is társulhat hozzájuk. Összel ritka, 2016-ig csak egy egyszer, 2014. november 2-án figyeltem meg 4 átrepülö példányt a sóderbánya területén, 2016. július 23. és 29. között viszont három különböző napon is észleltem a Turai-gyepen 6, ill. 10 példányt, ill. Kevermesen a belterület felett 6 egyedet. 


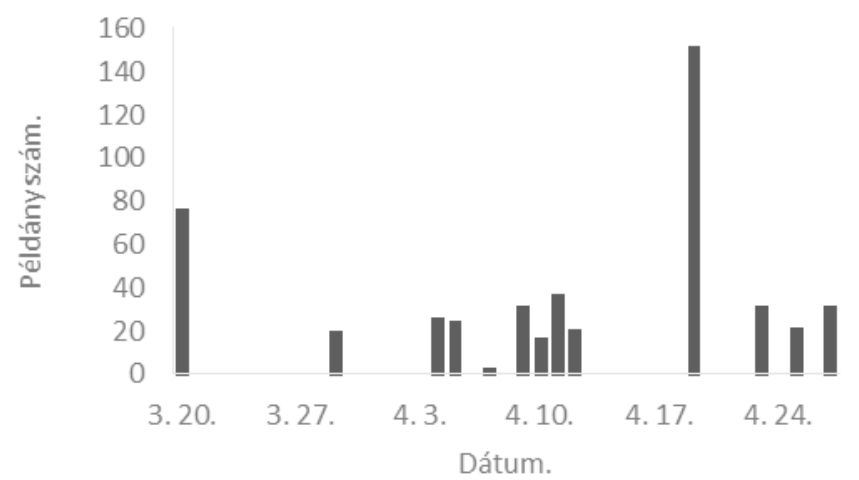

9. ábra. A kis póling tavaszi vonulási dinamikája.

Figure 9. Spring migration dynamics of whimbrel.

\section{Nagy póling (Numenius arquata)}

8 adata közül 3 a tavaszi, míg 5 a nyári, öszi időszakból származik (4. táblázat). A kis pólingnál egyértelmüen ritkább, csak alkalmilag tünik fel 1-1 magányos (kis pólingokhoz csatlakozott) példánya vagy kisebb csapata (2010. szeptember 11., sóderbánya, 6 átrepülő pld.; 2014. július 28., Kevermes belterület, 25 átrepülő pld.). Tavasszal március vége és április vége között lehet vele találkozni (legkorábbi megfigyelés: 2012. március 22., Kevermes, Marczibányi-dűlö, 1 pld.; legkésőbbi megfigyelés: 2013. április 27., Turai-gyep, 1 pld.), általában a Turai-gyepen, ill. a környezö belvizeken. Június vége és július vége között háromszor is felbukkant a területen. A tényleges őszi vonulás során éppúgy ritka, mint tavasszal, csupán egy augusztus végi és egy szeptember első feléből származó megfigyelése van.

4. táblázat. A nagy póling előfordulási adatai.

Table 4. Observation data of eurasian curlew.

\section{Időpont}

2010. szeptember 11.

2012. március 22.

2013. április 27.

2014. április 19.

2014. június 27.

2014. július 28 .

2016. július 28 .

2016. augusztus 25 .

\section{Példányszám}

1 Kevermes, belterület

1 Lőkösháza, Turai-gyep

1 Lőkösháza, Tulkán-gyep

2 Lőkösháza, Turai-gyep

25

1 Lőkösháza, Turai-gyep

1 Kevermes, sóderbánya
Megfigyelö(k)

Bozó L.

Bozó L.

Bozó L.

Bozó L.

Bozó L.

Bozó L.

Bozó L.

Bozó L. 


\section{Füstös cankó (Tringa erythropus)}

7 adata ismert két különböző évből, amelyből 4 a tavaszi, míg 3 a nyári időszakból való (5. táblázat). Kifejezetten a szántókon kialakult, nyílt belvizes foltokat kedveli, ezért nem meglepő, hogy 6 esetben 2013-ban került szem elé a Turai-gyep környékén. Tavasszal április közepe és május eleje között fordultak elö magányos madarak vagy 10 példányos összetartó csapatok, április végi és május eleji csúccsal (legkorábbi megfigyelés: 2016. április 12., Turai-gyeppel határos belvizes szántó, 1 pld.; legkésőbbi megfigyelés: 2013. május 4., Turai-gyeppel határos belvizes szántó, 10 pld.). Június végén és július elején kis számban mutatkozhat a még megmaradt belvizes foltokon. Öszi adata nincs.

5. táblázat. A füstös cankó előfordulási adatai.

Table 5. Observation data of spotted redshank.

Időpont

2013. április 27.

2013. május 02.

2013. május 04.

2013. június 28.

2013. július 01 .

2013. július 09 .

2016. április 12.
Példányszám

Terület

10

10

10

1

1

1

1
Lőkösháza, Turai-gyeppel határos belvizes szántó

Lőkösháza, Turai-gyeppel határos belvizes szántó

Lökösháza, Turai-gyeppel határos belvizes szántó

Lökösháza, Turai-gyeppel határos belvizes szántó

Lökösháza, Turai-gyeppel határos belvizes szántó

Lőkösháza, Turai-gyeppel határos belvizes szántó

Lőkösháza, Turai-gyeppel határos belvizes szántó
Megfigyelö(k)

Bozó L.

Bozó L.

Bozó L.

Bozó L.

Bozó L.

Bozó L.

Bozó L.

\section{Piroslábú cankó (Tringa totanus)}

Alkalmi fészkelő a Turai-gyep területén. Eddig csak 2010-ben és 2013-ban, a nagyobb belvizek idején telepedett meg a faj 1-1 párja. A fészkelő madarak május eleje és június legvége között tartózkodtak a területen. A fészek mindkét évben a gyeppel határos belvizes szántókon volt. 2013-ban sokáig 2 pár mozgott a területen, de csak az egyik pár fészkelését sikerült bizonyítani. A költési időszakból származó adatoktól eltekintve összesen 12 esetben figyeltem meg a fajt, kivétel nélkül a tavaszi vonulás során. A legfontosabb pihenő- és táplálkozóhely a piroslábú cankó esetében is a Turai-gyep menti belvizes területek, ugyanakkor számos adata van más belvizes foltokról is. Az első átvonuló csapatok március közepén érkeznek meg (legkorábbi megfigyelés: 2015. március 14., Turai-gyep, 5 pld.), a vonulás azonban csak április első felében tetőzik. Ekkor akár 60 példányt is számláló csapatai is elöfordulnak (legnagyobb csapat: 2013. április 6., Lökösháza, Tulkán-gyep, 60 pld.), de alapvetően nem jellemzőek a 10 példánynál nagyobb csapatai. Április utolsó hetében eltűnnek a vonulók (legkésőbbi megfigyelés: 2016. április 21., Turai-gyeppel határos belvizes szántó, 1 pld.) és csak a helyi állomány tagjai maradnak itt.

\section{Szürke cankó (Tringa nebularia)}

17 adata közül 8 a tavaszi, míg 9 a nyári-őszi időszakból származik (10. ábra). Egyike azon fajoknak, ami (föként ősszel) nem feltétlenül ragaszkodik a sekély vizü elöntésekhez, 
hanem a sóderbánya területén is rendszeresen feltűnik. Általában magányosan látható, őszszel például kizárólagosan, 2-4 példányos csapatai csak ritkán fordulnak elö (legnagyobb csapat: 2014. április 15., Kevermes belterület, 4 átrepülő pld.). Tavasszal egy szük, 3 hetes periódusban vonul át nálunk április 1. és 21. között (legkorábbi megfigyelés: 2013. április 1., Lőkösháza, Tulkán-gyep, 2 pld.; legkésőbbi megfigyelés: 2016. április 21., Turaigyeppel határos belvizes szántó, 1 pld.). Öszi vonulása július elején indul (legkorábbi megfigyelés: 2013. július 1., Turai-gyeppel határos belvizes szántó, 1 pld.) és egészen szeptember elejéig tart (legkésőbbi megfigyelés: 2012. szeptember 4., sóderbánya, 1 pld.).

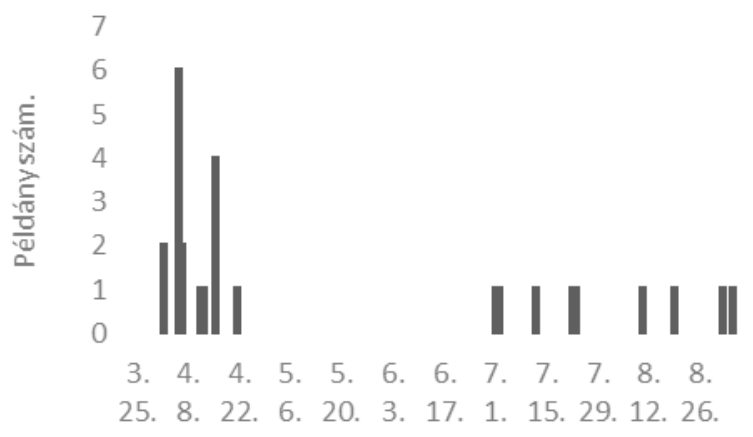

Dátum.

10. ábra. A szürke cankó éves vonulási dinamikája.

Figure 10. Annual migration dynamics of common greenshank.

\section{Erdei cankó (Tringa ochropus)}

27 adata egyenletesen oszlik meg a tavaszi, illetve a nyári-őszi periódusok közt (11. ábra). A billegetócankó mellett ez a másik faj, amelynek legtöbb adata a sóderbánya területéről származik (az adatok 60\%-a), tehát nem feltétlenül ragaszkodik a belvizekhez, ugyanakkor a tavasszal átvonulók mennyiségét mégis nagyban meghatározza a belvizes területek kiterjedése. Az is jellemző rá, hogy általában magányosan látható, még akkor is, ha több példány is a területen időzik. Tavasszal március második felében érkeznek vissza az elsők (legkorábbi megfigyelés: 2014. március 18., Turai-gyep, 1 átrepülő pld.), de a vonulás április első 3 hetében a legintenzívebb, május első hetében pedig az utolsók is eltűnnek (legkésőbbi megfigyelés: 2013. május 2., Turai-gyeppel határos belvizes szántó, 1 pld.). Öszi vonulása június végén kezdődik (legkorábbi megfigyelés: 2013. június 25., Kevermes. Kisházi-tó, 1 pld.) és egészen október közepéig elhúzódhat (legkésőbbi megfigyelés: 2016. október 14., sóderbánya, 1 pld.). Határozott őszi vonulási csúcs nincs. 


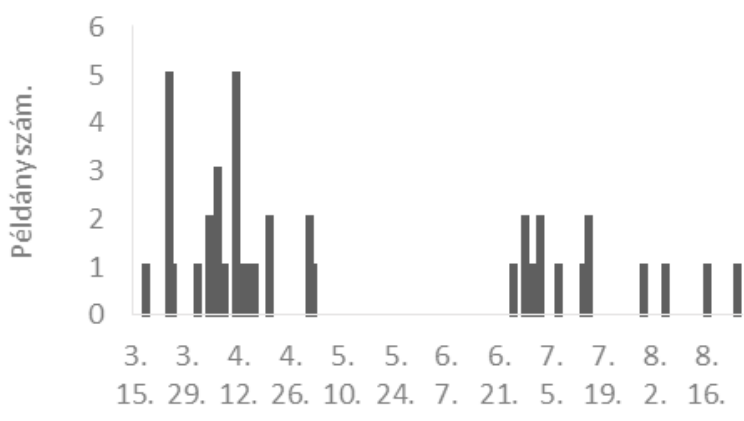

Dátum.

11. ábra. Az erdei cankó éves vonulási dinamikája.

Figure 11. Annual migration dynamics of green sandpiper.

\section{Réti cankó (Tringa glareola)}

23 adata ismert a térségből, amelyből 16 a tavaszi, míg 7 a nyári-őszi időszakból való (12. ábra). Az átvonulók mennyisége elsősorban a belvizek kiterjedésétől függ, ugyanakkor 7 nyári-öszi adata ismert a sóderbánya területéröl is. Tavasszal április első napjaiban érkeznek meg az elsők (legkorábbi megfigyelés: 2016. április 5., Turai-gyeppel határos belvizes szántó, 3 pld.), a vonulás a hó második fele és május első napjai között tetőzik. Ekkor akár 15-20 példány is a Turai-gyepen és környékén tartózkodhat egy időpontban. Nem feltétlenül mozognak együtt és gyakran az alacsony füvel benőtt részeket részesítik előnyben. Május közepéig az utolsók is elhagyják a térséget (legkésőbbi megfigyelés: 2013. május 9., Turai-gyeppel határos belvizes szántó, 2 pld.). Öszi vonulása július első felétől (legkorábbi megfigyelés: 2013. július 1., Turai-gyeppel határos belvizes szántó, 4 pld.) augusztus végéig tart (legkésőbbi megfigyelés: 2008. augusztus 20., sóderbánya, 1 pld.), csúcsa július első felében van.

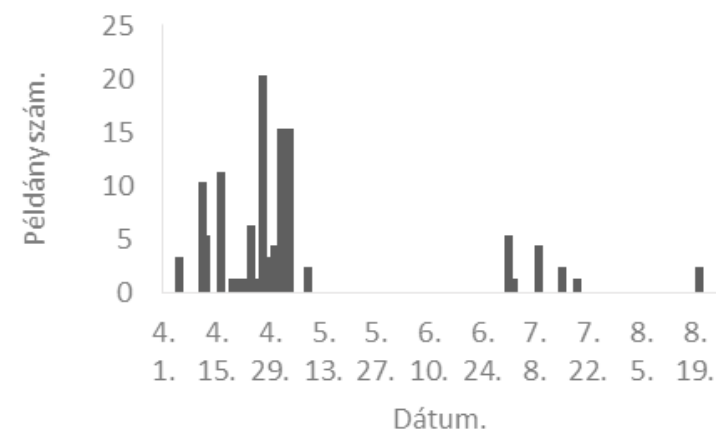

12. ábra. A réti cankó éves vonulási dinamikája.

Figure 12. Annual migration dynamics of wood sandpiper. 


\section{Billegetőcankó (Actitis hypoleucos)}

Azon kevés faj egyike, amelynek több nyári - őszi adata van (23), mint tavaszi (15) (13. ábra). További érdekesség, hogy csupán 7 esetben láttam 1 példánynál többet és akkor is 10 példány volt a maximum (2016. július 14., sóderbánya, 10. pld.). Az adatok 94,7\%-a a sóderbánya területéről származik, a Turai-gyepen csak egyszer, 2013. április 24-én figyeltem meg egy magányos példányt. Tavasszal az elsők rendszerint április 15. környékén érkeznek vissza, ennél korábban (2015. április 4.) csak egyszer figyeltem meg egy példányt a sóderbánya területén. Nincs egyértelmü csúcs, de az elmondható, hogy az egyszerre megfigyelt legtöbb példányt általában április utolsó hetében észleltem. Legkésőbbi adata 2010. május 7-éről származik a sóderbánya területéről. Öszi mozgalmuk június végén kezdődik el (legkorábbi megfigyelés: 2014. június 26., sóderbánya, 1 pld.), július közepe és vége között egy enyhe csúcs érzékelhető, de valójában augusztus végéig folyamatosan jelen a van a sóderbánya területén. Szeptemberben csak kétszer került szem elé, legkésőbb 2016. szeptember 15-én a sóderbánya területén ( 1 pld.).

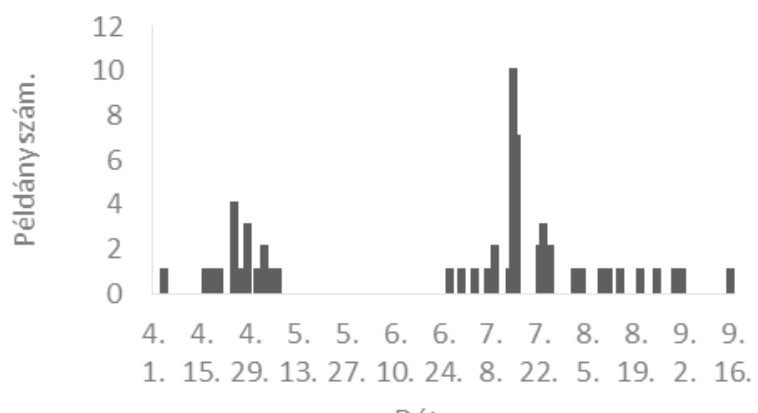

13. ábra. A billegetőcankó éves vonulási dinamikája.

Figure 13. Annual migration dynamics of common sandpiper.

\section{Dankasirály (Larus ridibundus)}

89 adata ismert a tárgyalt térségböl, amelyböl jól körvonalazódnak a faj lokális mozgalmai (14. ábra). Tavasszal március elejétől kezdődik el a tavaszi mozgásuk (legkorábbi megfigyelés: 2013. március 2., sóderbánya, 4 pld.), amely március és április fordulóján éri el a maximumát. Ekkor nemcsak a megfigyelések száma, hanem a megfigyelt madarak száma is jóval magasabb, mint az ezt megelőző és ezt követő időszakokban. Aprilis második felétől május végéig ugyan rendszeresen előkerül, de csak magányos példányok vagy néhány példányos csapatok. Júniusban nagyon ritka ( 3 adat), újabb hulláma július első felében éri el a térséget, majd augusztus elejétől kezdve már valószínüleg az őszi vonulók jelentkeznek. Ez egészen október legvégéig tart, nincsen egyértelműen meghatározható csúcsa. November elejétől február végéig éppúgy nagyon ritkán kerül szem elé, mint 
júniusban, csak szórványos adatai ismertek ebből az időszakból (általában magányos példányok, összesen 11 adat).

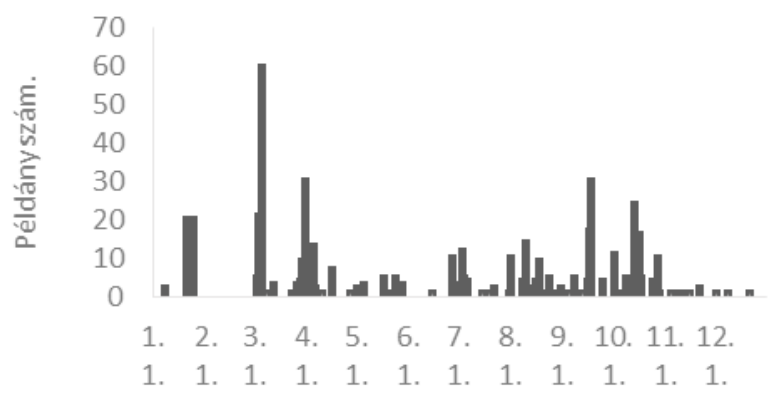

Dátum.

14. ábra. A dankasirály éves mozgásának dinamikája.

Figure 14. Annual dynamics of common black-headed gull.

\section{Viharsirály (Larus canus)}

14 adata ismert a térségböl, amelyek közül 13 a november eleje és március eleje közti időszakból származik. A legtöbb megfigyelés (4) decemberben történt. Általában a hidegebb periódusokban tủnnek fel magányos példányok vagy kisebb (max. 3 példányos, 2016. január 14., sóderbánya) csapatok a sóderbánya területén. Egyetlen júliusi adata van (2011. július $7 .$, sóderbánya, 2 pld.).

\section{Sárgalábú/Sztyeppi sirály (Larus michahellis/cachinnans)}

A nagysirályok térségünkben általában csak átrepülnek, megbízható határozásuk ezért sokszor nehézkes, így a két fajt együtt tárgyalom. Összesen 100 adatuk ismert, ezek túlnyomó többsége (79) az év második feléből származik (15. ábra). Januártól június közepéig csak alkalmilag bukkannak fel, nincsen jól körülírható tavaszi vonulásuk. A megfigyelések száma június második felében kezd el szaporodni, június és július fordulóján enyhe csúcs érzékelhető, amit arra vezetek vissza, hogy ekkor már zajlanak a gabona betakarítását követő talajmunkák, így a sirályok megfelelő mennyiségü táplálékot tudnak találni a térségben. Többször is feltüntek nagyobb, ilyen feltárcsázott földeken táplálkozó csapatok (legnagyobb: 2014. június 27., Turai-gyeppel határos learatott repceföld, 20 pld.). Egy enyhe visszaesést követően augusztus elejétől már minden bizonnyal az öszi átvonulókat lehet látni. Ez a folyamat egészen november végéig tart, a legintenzívebb október második és november első felében, de ezek az időszakok nem válnak el élesen a többitől. December elejére tulajdonképpen lecseng a vonulás, a december közepi újabb csúcsot már valószínúleg azok a madarak okozzák, amelyek a lehülés miatt délebbre vonulnak. 


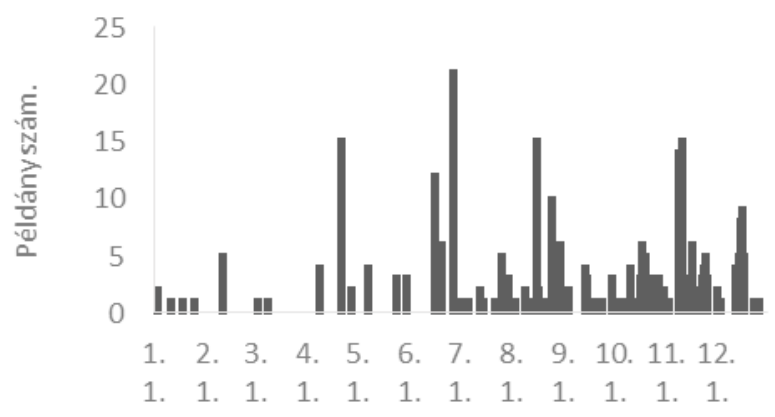

Dátum.

15. ábra. A sárgalábú/sztyeppi sirály éves mozgásának dinamikája.

Figure 15. Annual dynamics of yellow-legged/caspian gull.

\section{Küszvágó csér (Sterna hirundo)}

8 adata közül 4 a tavaszi, míg 4 a nyári időszakból származik (6. táblázat). Minden esetben a sóderbánya területén figyeltem meg magányos példányokat vagy kisebb (max. 5 példányos) csapatait. Tavasszal április második felében és május első hetében vonul át a térségben (legkorábbi megfigyelés: 2016. április 19., sóderbánya, 1 pld.). Ezt követően június 1. és július 1. között 5 különböző évben is feltünt. Öszi adata nincs.

6. táblázat. A küszvágó csér előfordulási adatai.

Table 6. Observation data of common tern.

\begin{tabular}{ccll}
\multicolumn{1}{c}{ Időpont } & Példányszám & \multicolumn{1}{c}{ Terület } & Megfigyelö(k) \\
\hline 2005. május 07. & 5 & Kevermes, belterület & Bozó L. \\
2005. június 23. & 4 & Kevermes, belterület & Bozó L. \\
2013. június 12. & 1 & Kevermes, sóderbánya & Bozó L. \\
2014. május 04. & 4 & Kevermes, belterület & Bozó L. \\
2015. július 01. & 1 & Kevermes, sóderbánya & Bozó L. \\
2016. április 19. & 1 & Kevermes, sóderbánya & Bozó L. \\
2016. április 28. & 1 & Kevermes, sóderbánya & Bozó L. \\
2016. június 03. & 1 & Kevermes, sóderbánya & Bozó L.
\end{tabular}

\section{Fattyúszerkő (Chlidonias hybrida)}

14 adata kivétel nélkül a tavaszi, ill. a nyári időszakból származik (16. ábra). Általában a sóderbánya területén kerültek szem elé, de belvizes években a Turai-gyep környékén is rendszeresen megfigyeltem magányos (más szerkőkkel együtt mozgó) példányokat vagy 
kisebb (max. 20 példányos) csapatokat. Az első madarak április közepén jelentkeznek és egészen május közepéig felbukkanhatnak átvonulók (legkorábbi megfigyelés: 2014. április 14., sóderbánya, 5 pld.; legkésőbbi megfigyelés: 2014. május 19., sóderbánya, 1 pld.). A vonulás csúcsa május első hetében van. Június eleje és vége között három különböző évben is megfigyeltem a területen, aminek oka az lehet, hogy ezek a példányok nem költöttek abban az évben, vagy valamilyen okból megsemmisült a költésük.

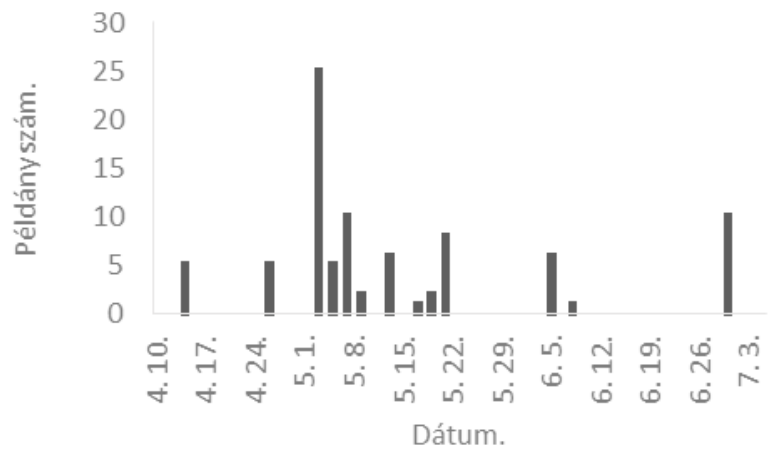

16. ábra. A fattyúszerkő éves mozgásának dinamikája.

Figure 16. Annual dynamics of whiskered tern.

\section{Kormos szerkö (Chlidonias niger)}

7 adata ismert a térségből, ezek egy kivételével a tavaszi időszakból származnak (7. táblázat). Általában más szerkőfajokkal láthatóak együtt magányosan vagy néhány példánnyal. Tavaszi vonulásuk rendkívül szük időszakon belül zajlik, mind a 6 megfigyelés április utolsó és május első hetében történt (legkorábbi megfigyelés: 2014. április 26., sóderbánya, 1 pld.; legkésőbbi megfigyelés: 2013. május 4., Turai-gyep, 4 pld.). Egy esetben 2014. június 5-én is szem elé került 2 példány a sóderbánya területén.

7. táblázat. A kormos szerkő előfordulási adatai.

Table 7. Observation data of black tern.

\begin{tabular}{ccll} 
Időpont & Példányszám & \multicolumn{1}{c}{ Terület } & Megfigyelö(k) \\
\hline 2007. április 30. & 2 & Kevermes, belterület & Bozó L. \\
2013. május 02. & 10 & Lőkösháza, Turai-gyep & Bozó L. \\
2013. május 04. & 6 & Lőkösháza, Turai-gyep & Bozó L. \\
2014. április 26. & 1 & Kevermes, sóderbánya & Bozó L. \\
2014. június 05. & 2 & Kevermes, sóderbánya & Bozó L. \\
2015. május 03. & 3 & Kevermes, sóderbánya & Bozó L. \\
2016. május 03. & 1 & Kevermes, sóderbánya & Bozó L.
\end{tabular}




\section{Ritka fajok adatai}

A rendszeresen átvonuló fajok mellett előfordult olyan eset is, amikor egy helyi szinten szokatlan, érdekes faj került szem elé. A Charadriiformes rend helyi képviselői között 10 ilyen fajt is találhatunk, amelyeket maximum 4 alkalommal figyeltem meg a térségben. Ezek adatait a 8. táblázat tartalmazza.

8. táblázat. Ritka fajok előfordulási adatai.

Table 8. Observation data of the rare species.

\begin{tabular}{|c|c|c|c|c|}
\hline Faj & Időpont & Példányszám & Terület & Megfigyelők \\
\hline $\begin{array}{l}\text { Parti lile } \\
\text { (Charadrius } \\
\text { hiaticula) }\end{array}$ & 2013. május 2. & 1 & Lőkösháza, Turai-gyep & Bozó L. \\
\hline \multirow{3}{*}{$\begin{array}{l}\text { Ezüstlile } \\
\text { (Pluvialis } \\
\text { squatarola) }\end{array}$} & 2013. április 9. & 1 & Kevermes, fácántelep & Bozó L. \\
\hline & 2014. október 18 . & 4 & Kevermes, sóderbánya & Bozó L. \\
\hline & 2014. október 20. & 1 & Kevermes, Bécsi-dűlő & Bozó L. \\
\hline $\begin{array}{l}\text { Fenyérfutó } \\
(\text { Calidris alba })\end{array}$ & 2015. aug. 23 . & 1 & Kevermes, sóderbánya & Bozó L. \\
\hline \multirow{2}{*}{$\begin{array}{l}\text { Apró partfutó } \\
\text { (Calidris minuta) }\end{array}$} & 2013. május 2. & 2 & Lőkösháza, Turai-gyep & Bozó L. \\
\hline & 2013. május 13. & 1 & Lőkösháza, Turai-gyep & Bozó L. \\
\hline \multirow{3}{*}{$\begin{array}{l}\text { Havasi partfutó } \\
\text { (Calidris alpina) }\end{array}$} & 2013. május 4. & 1 & Lőkösháza, Turai-gyep & Bozó L. \\
\hline & 2013. május 9. & 4 & Lőkösháza, Turai-gyep & Bozó L. \\
\hline & 2015. április 16. & 6 & Lőkösháza, Turai-gyep & Bozó L. \\
\hline \multirow{3}{*}{$\begin{array}{l}\text { Kis sárszalonka } \\
\text { (Lymnocryptes } \\
\text { minimus) }\end{array}$} & 2013. május 13. & 1 & Lőkösháza, Turai-gyep & Bozó L. \\
\hline & 2014. szept. 29. & 1 & Lőkösháza, Turai-gyep & Bozó L. \\
\hline & 2015. április 16 . & 1 & Lőkösháza, Turai-gyep & Bozó L. \\
\hline \multirow{4}{*}{$\begin{array}{l}\text { Nagy goda } \\
(\text { Limosa limosa) }\end{array}$} & 2006. július 5 . & 2 & Kevermes, belterület & Bozó L. \\
\hline & 2007. április 6 . & 4 & Kevermes, belterület & Bozó L. \\
\hline & 2007. április 8 . & 4 & Kevermes, belterület & Bozó L. \\
\hline & 2015. március 14. & 2 & Lőkösháza, Turai-gyep & $\begin{array}{l}\text { Bozó L., } \\
\text { Csathó A. I. }\end{array}$ \\
\hline \multirow{3}{*}{$\begin{array}{l}\text { Tavi cankó } \\
\text { (Tringa stagnatilis) }\end{array}$} & 2014. április 15. & 1 & Lőkösháza, Turai-gyep & Bozó L. \\
\hline & 2015. április 16 . & 1 & Lőkösháza, Turai-gyep & Bozó L. \\
\hline & 2016. április 12. & 1 & Lőkösháza, Turai-gyep & Bozó L. \\
\hline $\begin{array}{l}\text { Kis sirály } \\
\text { (Larus minutus) }\end{array}$ & 2014. május 5. & 2 & Kevermes, sóderbánya & Bozó L. \\
\hline \multirow{3}{*}{$\begin{array}{l}\text { Fehérszárnyú } \\
\text { szerkő } \\
\text { (Chlidonias } \\
\text { leucopterus) }\end{array}$} & 2013. május 4. & 3 & Lőkösháza, Turai-gyep & Bozó L. \\
\hline & 2014. április 28. & 1 & $\begin{array}{l}\text { Kevermes, Marczibányi- } \\
\text { dűlö }\end{array}$ & Bozó L. \\
\hline & 2015. május 10. & 7 & Kevermes, sóderbánya & Bozó L. \\
\hline
\end{tabular}




\section{Értékelés}

Több tanulmány is foglalkozott a Dél-Alföld vizes élőhelyein előforduló partimadarakkal, ugyanakkor ezek általában nemzeti parki törzsterületek voltak (KACZKÓ 1992, KotyMÁN 1996, STeRbetz 1993, Tóthné HANYECZ 2006, ZALAi 1999), a Csanádihát agrártájában nem történt hasonló vizsgálat ezt megelőzően. A Csanádi-hátra nem feltétlenül a partimadárfajok miatt figyelnek oda a kutatók (mindinkább a löszgyepekre, mezsgyékre; CSATHÓ 2008), ennek ellenére a Charadriiformes madárrendbe tartozó 34 faj legalább egyszeri előfordulását bizonyítottam Kevermesen, ill. a lökösházi Turai-gyepen. A 34 faj közül 5 fészkelt már a tárgyalt térségben, 19 faj rendszeres vendég az év valamely szakában, míg 10 faj 5-nél kevesebb esetben került szem elé. Az eddigi eredmények alapján a térségben fészkelő és átvonuló fajok száma a tavaszi belvizek kiterjedésének függvényében alakul. Nagyobb belvizek idején nemcsak több faj fordul meg a térségben, hanem azok sokkal nagyobb egyedszámban is képviseltetik magukat. A belvizek mennyisége a költési sikert is meghatározza, hiszen az aszályos években, amikor a tavaszi vizek már május első felére teljesen kiszáradnak, csak a bíbic és a kis lile képes sikeresen költeni. A gulipán és gólyatöcs fészkek nagy része még állandó vízborítás mellett is elpusztul, aminek nincs nyilvánvaló oka. A gólyatöcs kivételével egyik fészkelö faj sem költött még természetes gyepen, mindegyik a szántóföldeket részesítette elönyben, holott azok sokkal hamarabb kiszáradnak, mint a gyep. A kis lile az egyetlen faj, amely a mesterséges bányatavaknál rendszeresen költ, gyakran erősen zavart környezetben. A többi faj valószínüleg nem tolerálja az ilyen mértékü zavarást, illetve az alkalmas fészkelőhelyek száma is korlátozott itt. Hasonló eredményt kaptam az átvonuló fajokkal kapcsolatban is, a billegetőcankó és a viharsirály kivételével minden egyéb faj a belvizeken került elő legnagyobb számban, ami feltehetően az elérhető táplálék miatt alakul így. A tavakon nincsenek zátonyok, padkák, ahol tudnának táplálkozni, vagy egyáltalán pihenni. A billegetőcankó elsősorban olyan folyószakaszokon költ, amelyek nagyobb területü és számú, növénytakaróval kevésbé sürün benőtt zátonyokkal rendelkeznek (HAMMER et al. 2013). Ezek az élőhelyek hasonlítanak a kevermesi bányatavakhoz, ezért minden bizonnyal ennek köszönhető, hogy elsősorban ezt preferálja a belvizekkel szemben. A viharsirály pedig télen jelentkezik nálunk, amikor csak a bányatavakon talál nyílt vízfelületet. A legtöbb faj április eleje és május eleje között vonul át a térségben, ezért nagyon fontos, hogy ebben az időszakban megfelelö vízállás legyen az érintett területeken, különben a legtöbb faj elmarad és költeni sem maradnak vissza. A legtöbb faj esetében a vonulási időszakok mind tavasszal, mind ősszel megfelelnek a Magyarországon általánosan megfigyelt mintázattal (BOROS \& LENGYEL 2009, MOGYORÓSI \& PELlinger 2009a, 2009b LIKER 2009, HADARICS \& LACZIK 2009, HADARICS 2009a, 2009b, 2009c, 2009d, 2009e, 2009f, 2009g, FARAGÓ 2009, PELlingER \& FERENCZi 2009, HAJTÓ \& HORVÁTH 2009, Sós 2009a, 2009b), ugyanakkor néhány faj esetében kisebb eltéréseket tapasztalhatunk. A gólyatöcs jellemzően 2-3 héttel később érkezik meg tavasszal, mint ahogy azt az irodalomban említik (MME NOMENCLATOR BIZOTTSÁG 2008, BOROS 2009), míg az aranylile tavaszi vonulásának tetőzése 2 héttel korábbra esik az országos átlaghoz képest (HADARICS \& PELLINGER 2009). A szürke cankó helyi tavaszi mozgalma április közepén véget ér, holott az országban általában mindez május közepéig húzódik el (HADARICS 2009h). A dankasirály esetében a Dunakanyarban végzett megfigyelések (HORVÁTH \& SZINAI 2009a) hasonló eredményeket hoztak, mint amit én is kaptam, annyi kivétellel, hogy Kevermesen és Lőkösházán nincs a fajnak téli tetőzése, épp ellenkezőleg, 
kifejezetten ritkának számít. Ennek hátterében az állhat, hogy a Csanádi-háton nincsenek a Dunához hasonló nagyobb vízfelületek, ahol ez a faj le tudna szállni pihenni vagy táplálkozni, pedig ezek a madarak ezekre a helyekre koncentrálódnak. Érdekes jelenség a nagysirályok (sárgalábú és sztyeppi sirály) éves mozgalma, ezek ugyanis úgy tűnik, hogy a mezögazdasági földmunkákat követve mutatkoznak az év bizonyos szakaszain, amikor viszont a földeken nincsen számukra könnyen elérhető táplálék, nem is jelentkeznek. Az irodalmi adatokkal összevetve érdemes megemlíteni, hogy a nálunk késő ősszel nagyobb számban megfigyelt madarak valószínüleg sztyeppi sirályok, mivel ekkor a Dél-Alföldön nagyobb mozgalma van ennek a fajnak (HORVÁTH \& SZINAI 2009b). Az összel átvonuló madarak mennyisége a legtöbb faj esetében töredéke a tavasszal tapasztalhatónak, aminek egyértelműen a megfelelő vizes élőhelyek hiánya az oka. Ezt mi sem bizonyítja jobban, mint az a tény, hogy ekkor általában átrepülő egyedek kerülnek szem elé. A ritka fajok többsége is a kifejezetten belvizes években került szem elé. Eredményeimnek köszönhetően sikerült tehát pontos képet kapni egy agrártáj partimadár mozgalmairól és így későbbi vizsgálatok során összehasonlíthatóvá válik ezen területek madárvilága a jól kutatott vizes élőhelyekkel.

Köszönetnyilvánítás. A madártani felmérésekben végzett segítségéért köszönettel tartozom Bozóné BORBÁTH ERNÁnak, ROZGONYI JÁNOSnak és FrANK MÁTÉnak.

\section{Irodalomjegyzék}

Boros, E. (2009): Gólyatöcs. In: CsÖrgö, T., KarcZa, Zs., Halmos, G., Magyar, G., GyurÁcz, J., SzÉP, T., BAnkovics, A., ScmidT, A. \& Schmidt, E. (eds): Magyar Madárvonulási Atlasz. Kossuth Kiadó, Budapest, pp. 272.

Boros, E. \& Lengyel, Sz. (2009): Gulipán. In: CsÖrgö, T., KarcZA, Zs., Halmos, G., Magyar, G., GyurÁcz, J., SzÉP, T., BANKovics, A., SCMIDT, A. \& SCHMIDT E. (eds): Magyar Madárvonulási Atlasz. Kossuth Kiadó, Budapest, pp. 273-275.

Bozó, L. (2015a): Kevermes és a lőkösházi Turai-gyep madárvilága 2001-2015 január. A Puszta 25: $225-250$.

BozÓ, L. (2015b): Telelő és átvonuló énekesmadarak Békés megye délkeleti részén. A Puszta 25 : $217-224$.

BozÓ, L. (2015c): A kevermesi sóderbánya madarai a téli időszakban. A Puszta 25: 251-258.

BozÓ, L., BozÓNÉ BorBÁTH, E. \& TAR, L. (in press.): A fasorok és vízelvezető csatornák jelentősége a madárvonulásban. Természetvédelmi Közlemények

Bozó, L. (2017): Kevermes madárvilága. Dél-békési Természetvédelmi és Madártani Egyesület, Kevermes, $123 \mathrm{pp}$.

Csathó, A. I. (2008): Mezsgyék kutatása a Körös-Maros Nemzeti Park Igazgatóság müködési területén. Kutatási jelentés, Körös-Maros Nemzeti Park Igazgatóság, Szarvas, 132 pp.

Csathó, A. I. \& Csathó, A. J. (2009): A dombegyházi Battonyai út egy védelmet érdemlő mezsgyeszakaszának flórája. Crisicum 6: 33-57.

FAragó, S. (2009): Erdei szalonka. In: Csörgö, T., KarcZa, Zs., Halmos, G., Magyar, G., GyurÁcz, J., SzÉP, T., BANKovics, A., SCMIDT, A. \& SCHMIDT, E. (eds): Magyar Madárvonulási Atlasz. Kossuth Kiadó, Budapest, pp. 304-305. 
Hadarics, T. (2009a): Sárszalonka. In: CsÖrgö, T., KArcZa, Zs., Halmos, G., Magyar, G., GyurÁcz, J., Szép, T., BANKovics, A., SCMIDT, A. \& SChMidT, E. (eds): Magyar Madárvonulási Atlasz. Kossuth Kiadó, Budapest, pp. 300-303.

HAdARICS, T. (2009b): Nagy sárszalonka. In: CsÖRGÖ, T., KARCZA, Zs., Halmos, G., MaGYAR, G., GyurÁcz, J., SzÉP, T., BAnKovics, A., SCMIDT, A. \& SChMidT, E. (eds): Magyar Madárvonulási Atlasz. Kossuth Kiadó, Budapest, pp. 304.

HADARICS, T. (2009c): Kis póling. In: CsÖRGÖ, T., KARCZA, Zs., HAlmos, G., MAGYAR, G., GyurÁCZ, J., SzÉp, T., BAnkovics, A., ScmidT, A. \& SchmidT, E. (eds): Magyar Madárvonulási Atlasz. Kossuth Kiadó, Budapest, pp. 308.

Hadarics, T. (2009d): Nagy póling. In: CsÖrgö, T., KarcZA, Zs., Halmos, G., Magyar, G., GyurÁcz, J., SzÉp, T., BAnKovics, A., Scmidt, A. \& SchmidT, E. (eds): Magyar Madárvonulási Atlasz. Kossuth Kiadó, Budapest, pp. 310.

Hadarics, T. (2009e): Piroslábú cankó. In: CsÖrgö, T., Karcza, Zs., Halmos, G., Magyar, G., GyurÁcz, J., SzÉP, T., BANKovics, A., SCMIDT, A. \& SCHMIDT, E. (eds): Magyar Madárvonulási Atlasz. Kossuth Kiadó, Budapest, pp. 313-315.

HAdArics, T. (2009f): Erdei cankó. In: CsÖRgÖ, T., KARCZA, Zs., Halmos, G., Magyar, G., GyurÁcz, J., SzÉP, T., BANKovics, A., SCMIDT, A. \& SChmidT, E. (eds): Magyar Madárvonulási Atlasz. Kossuth Kiadó, Budapest, pp. 317-318.

HAdArics, T. (2009g): Billegetőcankó. In: CsÖrgö, T., KARCZA, Zs., Halmos, G., MAGYAR, G., GyurÁcz, J., SzÉP, T., BAnKovics, A., ScMidt, A. \& SchmidT, E. (eds): Magyar Madárvonulási Atlasz. Kossuth Kiadó, Budapest, pp. 321-322.

Hadarics, T. (2009h): Szürke cankó. In: Csörgö, T., KarcZA, Zs., Halmos, G., Magyar, G., Gyurácz, J., SzÉp, T., BAnkovics, A., ScMidt, A. \& SchmidT, E. (eds): Magyar Madárvonulási Atlasz. Kossuth Kiadó, Budapest, pp. 316.

Hadarics, T. \& LacziK, D. (2009): Pajzsoscankó. In: CsÖrgö, T., KarCZA, Zs., Halmos, G., MAGYAR, G., GyUrÁCZ, J., SzÉP, T., BAnKovics, A., SCMidT, A. \& SCHMidT, E. (eds): Magyar Madárvonulási Atlasz. Kossuth Kiadó, Budapest, pp. 298-299.

Hadarics, T. \& Pellinger, A. (2009): Aranylile. In: Csörgő, T., Karcza, Zs., Halmos, G., MAGyAr, G., Gyurácz, J., SzÉP, T., BAnkovics, A., Scmidt, A. \& Schmidt, E. (eds): Magyar Madárvonulási Atlasz. Kossuth Kiadó, Budapest, pp. 283.

Hajtó, L. \& Horváth, G. (2009): Viharsirály. In: CsÖrgö, T., KARCZA, Zs., Halmos, G., Magyar, G., GyurÁcz, J., SzÉP, T., BAnKovics, A., SCMIDT, A. \& SchmidT, E. (eds): Magyar Madárvonulási Atlasz. Kossuth Kiadó, Budapest, pp. 335-336.

Hammer, T., Liker, A. \& SzentiRmai, I. (2013): Habitat preference of Common Sandpipers (Actitis hypoleucos) along the River Rába, Hungary. Ornis Hungarica 21(1): 26-35. https://doi.org/10.2478/orhu-2013-0013

Horváth, G. \& Szinai, P. (2009a): Dankasirály. In: CsÖRGÖ, T., KARCZA, Zs., Halmos, G., Magyar, G., GyurÁcz, J., SzÉP, T., BANKOvics, A., SCMIDT, A. \& SCHMIDT, E. (eds): Magyar Madárvonulási Atlasz. Kossuth Kiadó, Budapest, pp. 331-334.

Horváth, G. \& SzinaI, P. (2009b): Ezüstsirály, sárgalábú sirály, sztyeppi sirály. In: CsÖRGÖ, T., Karcza, Zs., Halmos, G., Magyar, G., Gyurácz, J., Szép, T., Bankovics, A., Scmidt, A. \& SchmidT, E. (eds): Magyar Madárvonulási Atlasz. Kossuth Kiadó, Budapest, pp. 338-340.

KACZKÓ, Á. (1992): 1992-es tavaszi limikola vonulás Kardoskúton (01.01.-07.31.). Partimadár 1(2): $25-28$. 
Kotymán, L. (1996): A gólyatöcs (Himantopus himantopus) és a gulipán (Recurvirostra avosetta) élőhelyeinek és állománynagyságának felmérése Hódmezővásárhely környékén 1995-ben. Partimadár 5: 22-26.

Kotymán, L. (2003): Partimadarak (Charadrii) állománymozgalma 2003-ban a Dél-Tiszántúlon. $A$ Puszta 1/20: 39-52.

Liker, A. (2009): Bíbic. In: CsÖrgÖ, T., KARCZA, Zs., Halmos, G., Magyar, G., GyurÁcz, J., SzÉP, T., Bankovics, A., ScmidT, A. \& SChMidt, E. (eds): Magyar Madárvonulási Atlasz. Kossuth Kiadó, Budapest, pp. 284-287.

MME Nomenclator BizotTsÁG (2008): Magyarország madarainak névjegyzéke. Nomenclator avium Hungariae. Magyar Madártani és Természetvédelmi Egyesület, Budapest, 278 pp.

Mogyorósi, S. \& Pellinger, A. (2009a): Kis lile. In: Csörgö, T., KarcZA, Zs., Halmos, G., MAGyAr, G., Gyurácz, J., SzÉP, T., BAnkovics, A., SCMIDT, A. \& SCHMidT, E. (eds): Magyar Madárvonulási Atlasz. Kossuth Kiadó, Budapest, pp. 277-278.

Mogyorósi, S. \& Pellinger, A. (2009b): Füstös cankó. In: CsÖrgÖ, T., Karcza, Zs., Halmos, G., Magyar, G., Gyurácz, J., SzÉP, T., BAnkovics, A., ScMidt, A. \& Schmidt, E. (eds): Magyar Madárvonulási Atlasz. Kossuth Kiadó, Budapest, pp. 312.

Pelle, F. (2003): Kevermes története. Ipszilon Kiadó, Békéscsaba, 421 pp.

Pellinger, A. \& Ferenczi, M. (2009): Réti cankó. In: CsörgÖ, T., KARCZA, Zs., Halmos, G., MAGyar, G., GyurÁcz, J., SzÉP, T., BAnKovics, A., SCMidT, A. \& SCHMidT, E. (eds): Magyar Madárvonulási Atlasz. Kossuth Kiadó, Budapest, pp. 319-320.

Sós, E. (2009a): Fattyúszerkő. In: CsÖrgö, T., KArczA, Zs., Halmos, G., MaGyar, G., Gyurácz, J., SzÉP, T., BANKovics, A., SCMIDT, A. \& SchmidT, E. (eds): Magyar Madárvonulási Atlasz. Kossuth Kiadó, Budapest, pp. 345-346.

Sós, E. (2009b): Kormos szerkő. In: CsÖRGÖ, T., KARCZA, Zs., Halmos, G., MAGYAR, G., GyurÁcz, J., SzÉP, T., BAnkovics, A., Scmidt, A. \& SchmidT, E. (eds): Magyar Madárvonulási Atlasz. Kossuth Kiadó, Budapest, pp. 347-348.

SterbetZ, I. (1993): Migration of the Curlew Sandpiper (Calidris ferruginea) in the South-East of the Hungarian Plain. Aquila 100: 181-188.

STERBETZ, I. (1995): A délkelet-magyarországi bíbic- (Vanellus vanellus) populáció harmincéves vizsgálata. Aquila 102: 41-52.

TARDY, J. (2007): A magyarországi vadvizek világa - Hazánk ramsari területei. Alexandra, Pécs, 416 pp.

Tóтн, T. (2003): Újabb adatok a Dél-Tiszántúl flórájának ismeretéhez. A Puszta 20: 135-169.

TÓTHNÉ HANYeCZ, K. (2006): Természetvédelmi kezelési elvek és módszerek. Kezelési javaslatok a Körös-Maros Nemzeti Park védett természeti területeire. Doktori értekezés, Budapest, 137 pp.

ZALAI, T. (1999): Biharugra - egy Hortobágytól eltérő vadlúdvonulási útvonal. Crisicum 2: 215-219. 


\title{
Migration and breeding of the species of Charadriiformes in the area of Kevermes and Lőkösháza
}

\author{
LÁSZLó BOZÓ \\ Battonyai u. 10, H-5744 Kevermes, Hungary \\ E-mail: bozolaszlo91@gmail.com
}

ÁLLATTANI KÖZLEMÉNYEK (2017) 102(1-2): 25-49.

\begin{abstract}
During my work I studied the migration and the breeding of the members of Charadriiformes in the Csanádi-hát around Kevermes and Lökösháza, in Southeast Hungary. Between 2004 and 2016, 34 different species were observed in the study region. Most of them just migrate through the area while only 5 species breed there regularly. Abundances of both the migratory and the breeding species depend primary on the extent of internal waters and the rarities occured also only in case of higher water levels. Most species preferred the arable lands with internal waters compared to the querry pond and there were much smaller specimen-numbers in autumn than in spring, due to the drying up of waters. The common sandpiper uses both in spring and in autumn primarily the querry ponds, as well as the common gull does it in winter. This study revealed, that the agricultural lands have an important role in the migration of the shorebirds.
\end{abstract}

Keywords: shorebirds, bird migration, internal waters, Csanádi-hát 